\title{
Water Production by Condensation of Wet Air
}

\author{
Louis Okotaka Ebale*, Guy Dieudonne Moukandi N'kaya, Wilfrid Kombo, Feldha Kibongani \\ Laboratoire de Mécanique, Energétique et Ingénierie, Ecole Nationale Supérieure Polytechnique, Université Marien Ngouabi, \\ Brazzaville, Congo \\ Email: *dajlouis@yahoo.fr
}

How to cite this paper: Ebale, L.O., N'kaya, G.D.M., Kombo, W. and Kibongani, F. (2020) Water Production by Condensation of Wet Air. Modern Mechanical Engineering, 10, 17-24. https://doi.org/10.4236/mme.2020.102002

Received: May 15, 2020

Accepted: May 26, 2020

Published: May 29, 2020

Copyright (C) 2020 by author(s) and Scientific Research Publishing Inc. This work is licensed under the Creative Commons Attribution International License (CC BY 4.0).

http://creativecommons.org/licenses/by/4.0/

(c) (i) Open Access

\begin{abstract}
It is now assumed that climate warming is effective and noticeable. It not only leads to a lack of water that is increasing in desert areas, but it must be kept in mind that the inhabitants of the villages located in the geographical areas whose access to water is difficult, make binding efforts to gain access to water. This article proposes to present the possibility of obtaining water by the condensation of the water vapors of the air by applying the thermodynamic processes of the humid air as well as those of the refrigerating installations. In fact, atmospheric air contains suspended water vapors. When this steam cools below its rose point, there is condensation if water vapors and liquid water or ice appears. It was obtained a quantity of condensed vapors in a refrigeration facility. This amount is directly proportional to the refrigeration power whose efficiency can be improved by the use of photovoltaic energy given the reduced financial cost of this energy. This seems to be a hope among the possible solutions to be considered for the resolution of the water issue.
\end{abstract}

\section{Keywords}

Refrigeration Installation, Satured Wet Air, Condensed Vapors,

Dew Temperature

\section{Introduction}

Today, at least that is forecast by the experts in terms of forecasting, it is now clear that the global warming in progress is increasing and that a third of humanity is in a situation of water stress [1] [2] [3] [4] [5]. For villagers in geographical areas with difficult access to water, water supply is difficult and requests physical effort [6] [7] [8] [9]. However, a solution is possible by condensing the water vapor from the air. In fact, the atmospheric air contains in suspension water vapor, it is often in the state of superheated steam. When at a given temperature $\Theta$, humid air contains the maximum mass of water vapor that it can 
contain per kilogram of dry air, the air is said to be saturated [2] [3] [4]. In these particular conditions, the vapor pressure of the water in the air at the same value as the saturation vapor pressure of the water at the same temperature $\Theta$. This is the pressure that water vapor would take in equilibrium with liquid water or ice. Determination of the characteristics and processes that occur can be achieved by the thermodynamics of moist air using the psychometric diagram [10] [11]. Our study is carried out for tow climates, namely: the tropical climate and the desert climate (Figure 1). In contact with the evaporator whose temperature is very low, the moist air exchange heat because the temperature gradient, this results in a change in the phase of the water in the air. It goes from gaseous state to the liquid state, in other words, it condenses. This condensation can be forced, it is a forced convection if the circulation of air is carried out in a mechanic way, or natural way if the heat exchange is caused by the gradient of density. Note that the amount of condensed water depends not only on the climate in which the process occurs, but also on the speed with the air passes through the evaporator. This amount of water is directly proportional to the speed of air. The installation of Figure 4 represents a natural convection occurring in a tropical climate. On the evaporator, the water vapor of the air turns into ice, thanks to a system of regulation that stops for some time the electrical power of. During this moment, this ice turns into a liquid that flows by gravitation into the recipient. Water production is about 2 litres per 24 hours (Figure 6 and Figure 7).

\section{Materials and Method}

\subsection{Material}

Figures 2-4 show a refrigeration plant whose cooling capacity is $\mathrm{Q}_{\mathrm{o}}=155(\mathrm{~W})$

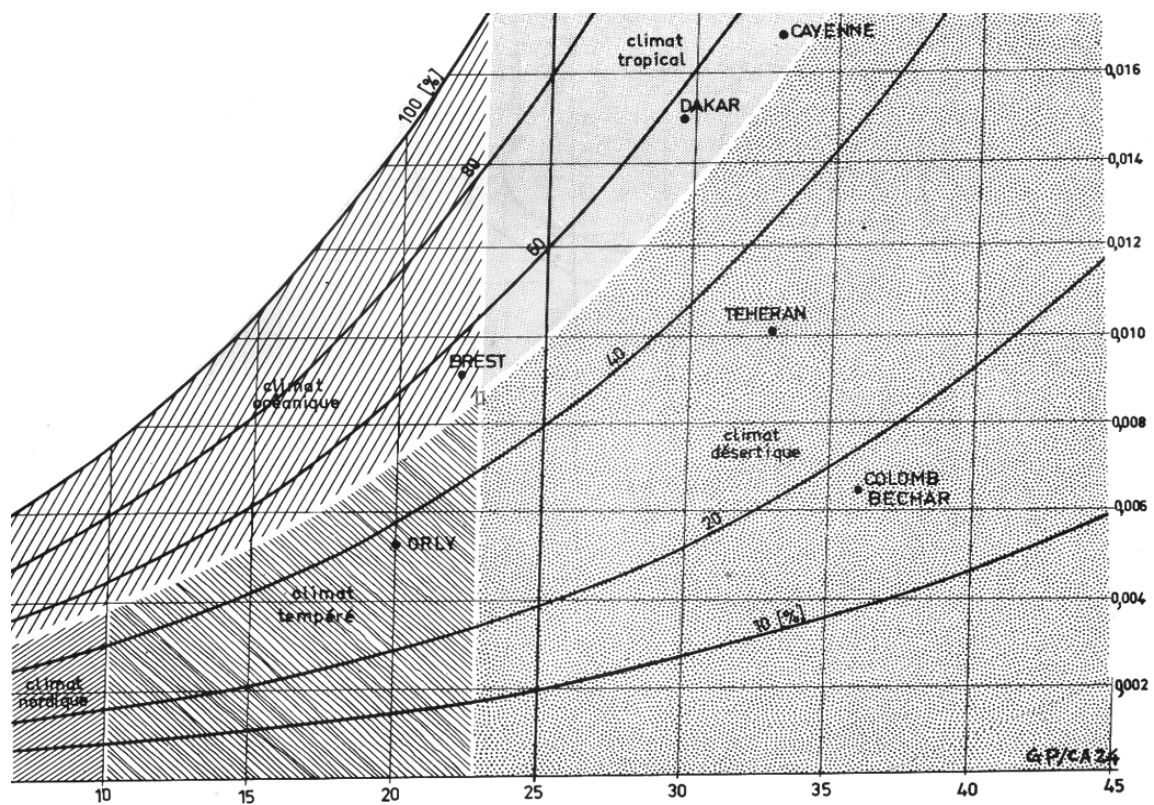

Figure 1. Representation in the psychrometric diagram of the characteristic zones of different climate. Source: Hot-Cold-Plumbing Paris Edition 1987. 


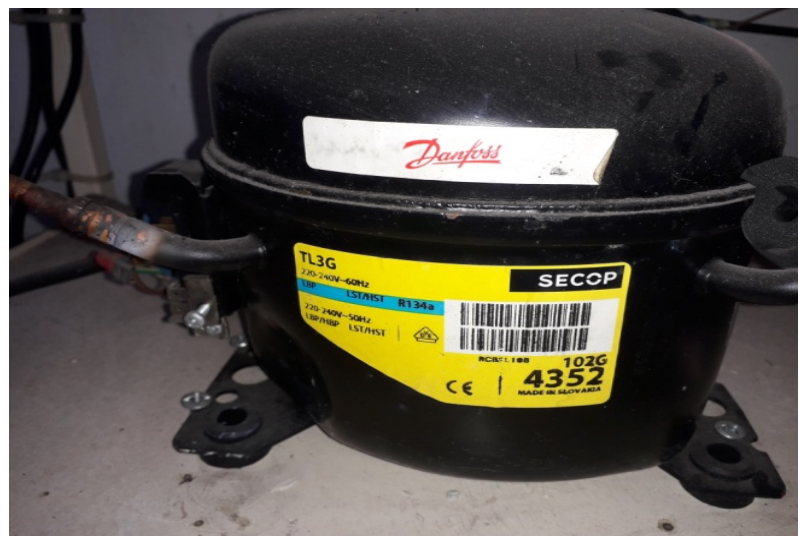

Figure 2. Universal compressor SECOP TL3G. R134a.



Figure 3. Evaporator VITRIFRIGO DANFOSS BD35.

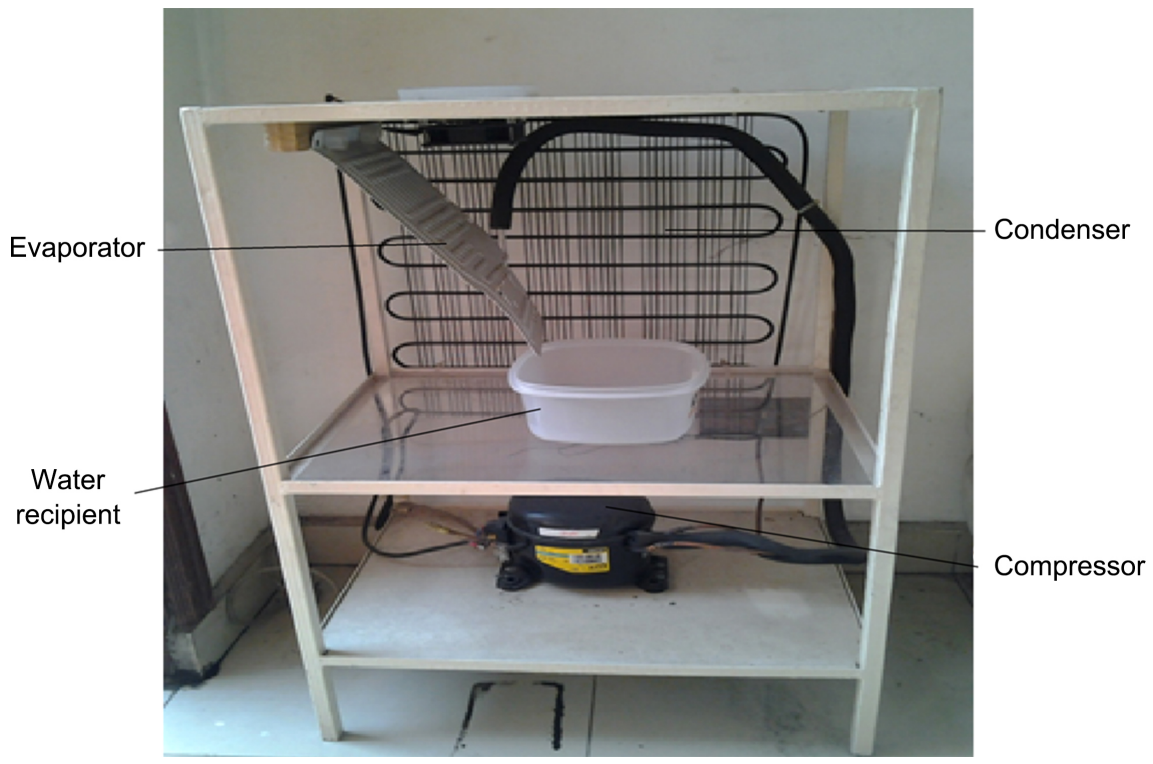

Figure 4. Representation of the refrigeration plant for water production.

equipped with air condenser, a Universal compressorSECOPTL3G. R134a 220/240 $\mathrm{V} 50 / 60 \mathrm{~Hz}$ with a power of $\mathrm{P}=111(\mathrm{~W})$, an Evaporator VITRIFRIGODANFOSS BD35F of L. $295 \mathrm{~mm} \times 1.125 \mathrm{~mm}$. This installation carries out the classic Carnot refrigeration cycle (compression, condensation, expansion, evaporation) with the R134a fluid. 


\subsection{Method}

Figure 5 shows the process of water production in the psychometric diagram whose ordinates represent the moisture contents $\mathrm{r}\left(\mathrm{kg} / \mathrm{kg}_{\mathrm{as}}\right)$ and the abscissa, the temperatures. In this figure, point 1 is the representative state of unsaturated humid air characterized by a temperature $\theta=35^{\circ} \mathrm{C}$ and hygrometry $\varphi=65 \%$ for the tropical climate and a humidity of $\varphi=35 \%$ for the climate desert. The progressive cooling of this air with a constant moisture content occurs along a horizontal line which, at a certain temperature $\theta_{\mathrm{R}}=27^{\circ} \mathrm{C}$ for the tropical climate and $\theta_{\mathrm{R}}=17^{\circ} \mathrm{C}$ for the desert climate, meets the saturation curve $\varphi=100 \%$. This temperature $\theta_{\mathrm{R}}$ is called the dew temperature or dew point, it is the saturation point of the water vapor of the air. If the temperature is reduced below the dew point, the evolution of saturated humid air then follows the saturation curve $\varphi=$ $100 \%$. The value of the content decreases, there is consequently condensation of water vapor, or the ice appearance when temperatures are very low in Figure 6 and Figure 7. The amount of condensed water per kilogram of dry air shall be equal to the difference between the moisture content at the dew point and the water content at the temperature of $\Theta=0^{\circ} \mathrm{C}$ [12] [13] [14]. Given that the compressor power is directly proportional to the cooling capacity of the evaporator, it is possible to calculate coefficient of refrigeration performance, the air flow rate and therefore the flow of condensed water [15] [16].

\subsubsection{Coefficient of Refrigeration Performance}

The performance coefficient of the installation C.O.P. is the ratio of refrigeration production $\mathrm{Q}_{0}$ by the electrical power consumed $\mathrm{P}$. It is calculated by the relationship:

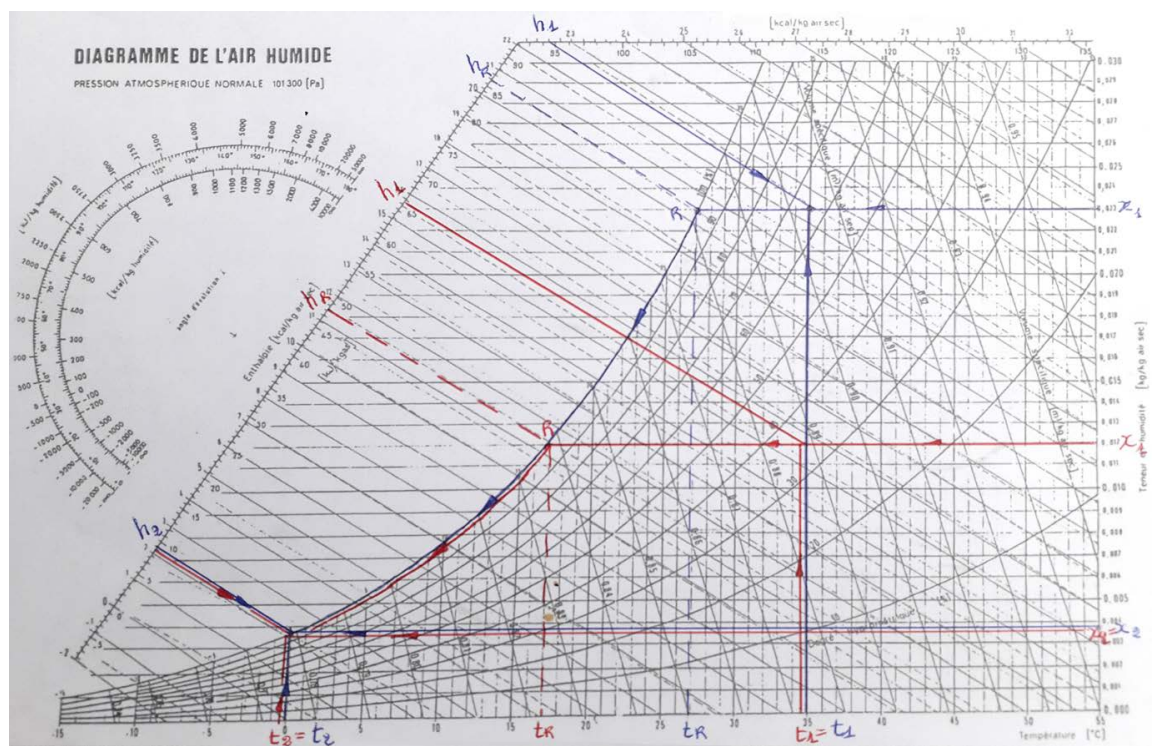

Figure 5. Representation in the psychometric diagram of the processes of the air cooling and condensation of water vapor: blue for the tropical climate. $\mathrm{h}_{1}=93.5 \mathrm{~kJ} / \mathrm{kg} ; \mathrm{x}_{1}=0.0023$ $\mathrm{kg} / \mathrm{kg}_{\mathrm{a}} ; \mathrm{h}_{2}=8.5 \mathrm{~kJ} / \mathrm{kg} ; \mathrm{x}_{2}=0.0035 \mathrm{~kg} / \mathrm{kg}_{\mathrm{a}}$; red for the desert climate. $\mathrm{h}_{1}=65 \mathrm{~kJ} / \mathrm{kg} ; \mathrm{x}_{1}=$ $0.0012 \mathrm{~kg} / \mathrm{kg}_{\mathrm{a}} ; \mathrm{h}_{2}=8.5 \mathrm{~kJ} / \mathrm{kg} ; \mathrm{x}_{2}=0.0035 \mathrm{~kg} / \mathrm{kg}_{\mathrm{a}}$. 


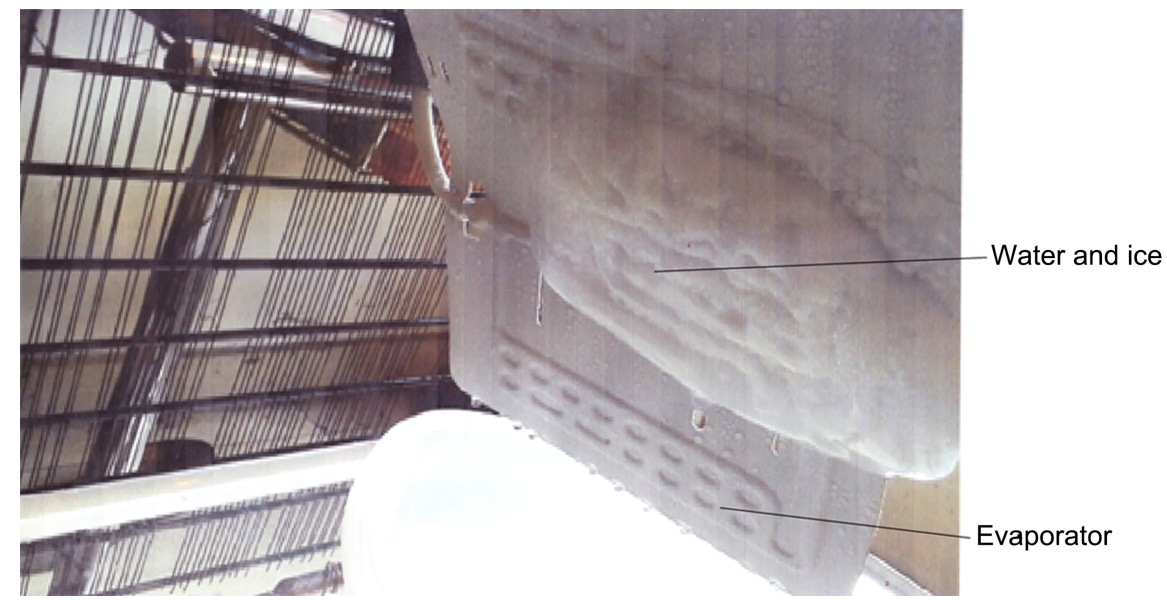

Figure 6. Production of water and ice water at the evaporator of the installation.

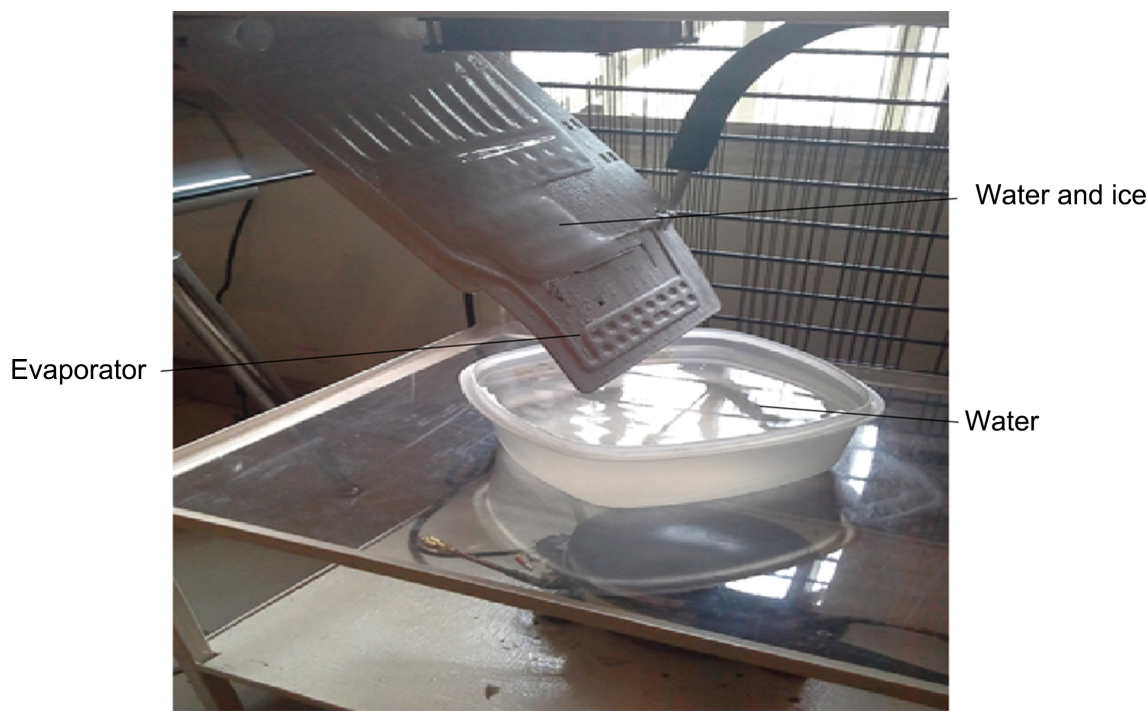

Figure 7. Obtaining water after ice defrosting.

$$
\text { C.O.P. }=\frac{Q_{0}}{P} \text {. }
$$

\subsubsection{Calculation of the Air Flow of the Installation}

The air flow $D_{\text {air }}$ passing through the evaporator is cooled in state (1) $\Theta_{1}=25^{\circ} \mathrm{C}$ and $\varphi=65 \%$ in state (2), $\Theta_{2}=0^{\circ} \mathrm{C}$ and $\varphi=100 \%$; corresponding to the cooling capacity $\mathrm{Q}_{0}$ supplied by the refrigeration system, is determined by the relation [10] [13] [14]:

$$
\begin{gathered}
\mathrm{Q}_{\mathrm{o}}=\mathrm{D}_{\text {air }}\left(\left|\mathrm{h}_{2}-\mathrm{h}_{1}\right|\right)=\mathrm{k} \cdot \mathrm{S} \cdot \Delta \mathrm{t}(\mathrm{kJ}) \\
\mathrm{D}_{\text {air }}=\frac{\mathrm{Q}_{\mathrm{o}}}{\left|\mathrm{h}_{2}-\mathrm{h}_{1}\right|}(\mathrm{kg} / \mathrm{h})
\end{gathered}
$$

$h_{1}$ : Enthalpy of air at state $\Theta_{1}\left(C^{\circ}\right) ; h_{2}$ : Enthalpy of air at state $\Theta_{2}\left(C^{\circ}\right)$; k: heat exchange coefficient $\left(\mathrm{kJ} / \mathrm{m}^{2} \cdot \mathrm{kg} \cdot \mathrm{C}^{\circ}\right) ; \Delta \mathrm{t}$ : gradient of temperature $\left(\mathrm{C}^{\circ}\right)$; S: evaporator heat exchange surface $\left(\mathrm{m}^{2}\right)$. 


\subsubsection{Calculation of the Water Flow of the Installation}

During the cooling of the air, when the air temperature drops below the dew point, $\varphi=100 \%$, there is saturation of the air, begins the condensation of the water vapor of the state (R) $18^{\circ} \mathrm{C}, \mathrm{h}_{\mathrm{R}}=52 \mathrm{~kJ} / \mathrm{k}$ gas in state (2); Knowing the air flow $\mathrm{D}_{\text {air }}$ according to relation (3), quantity of water $\mathrm{D}_{\text {water }}$ is determined by the relation [11] [15] [16]:

$$
\mathrm{D}_{\text {water }}=\mathrm{D}_{\text {air }}\left(\left|\mathrm{x}_{2}-\mathrm{x}_{1}\right|\right)
$$

With:

$\mathrm{x}_{1}$ : absolute humidity of the air at state $\Theta_{1}\left(\mathrm{~kg} / \mathrm{kg}_{\mathrm{a}}\right)$;

$\mathrm{x}_{2}$ : absolute humidity of the air at state $\Theta_{2}\left(\mathrm{~kg} / \mathrm{kg}_{\mathrm{a}}\right)$.

\section{Results and Discussion}

The purpose of this project is to produce water in areas where access to water is difficult. Table 1, Table 2 clearly indicate for the same power and the same ambient temperature, contrary to tropical climates, the production of water in desert climates is lower, namely: $D_{\text {water }}=0.124 \mathrm{~kg} / \mathrm{h}$ for the tropical zone respectively $\mathrm{D}_{\text {water }}=0.08 \mathrm{~kg} / \mathrm{h}$ and for the desert area. This is mainly due to the difference in hygrometry between tropical and desert climates picture 1 . This is not the case for the desert areas located at the seaside or the ocean which benefit from a very good hygrometry and high absolute humidity [3] [4]. However, it is possible to improve the flow of water by improving the convection and the conduction of the evaporator by improving the heat exchange coefficient $\mathrm{k}$ and increasing the surface and the air flow of the evaporator, in other words by increasing the cooling capacity of the installation, especially since in the desert climate this flow rate is higher than that of the tropical climate due to the lower enthalpy difference [3] [5]. In the desert areas, the temperature drops during the night, even if very early in the morning, the relative humidity varies positively for a very short time. However, this variation in temperature does not significantly influence the moisture content and therefore does not influence the flow of water produced by the installation [9] [10]. In order to improve the performance coefficient of the air condensation water production system, it would be

Table 1. Summary of the characteristics of the installation for a tropical climate.

\begin{tabular}{ccccccc}
\hline C.O.P & $\begin{array}{c}\mathrm{P} \\
(\mathrm{kW})\end{array}$ & $\begin{array}{c}\mathrm{Q}_{\mathrm{o}} \\
(\mathrm{kW})\end{array}$ & $\begin{array}{c}\left|\mathrm{h}_{2}-\mathrm{h}_{1}\right| \\
\left(\mathrm{kJ} / \mathrm{kg}_{\mathrm{a}}\right)\end{array}$ & $\begin{array}{c}\left|\mathrm{x}_{2}-\mathrm{x}_{1}\right| \\
\left(\mathrm{kg} / \mathrm{kg}_{\mathrm{a}}\right)\end{array}$ & $\begin{array}{c}\mathrm{D}_{\text {air }} \\
(\mathrm{kg} / \mathrm{h})\end{array}$ & $\begin{array}{c}\mathrm{D}_{\text {eau }} \\
(\mathrm{kg} / \mathrm{h})\end{array}$ \\
\hline 1.39 & 0.111 & 0.155 & 85 & 0.0195 & 6.38 & 0.124 \\
\hline
\end{tabular}

Table 2. Summary of the characteristics of the installation for a desert climate.

\begin{tabular}{ccccccc}
\hline C.O.P & $\begin{array}{c}\mathrm{P} \\
(\mathrm{kW})\end{array}$ & $\begin{array}{c}\mathrm{Q}_{\mathrm{o}} \\
(\mathrm{kW})\end{array}$ & $\begin{array}{c}\left|\mathrm{h}_{2}-\mathrm{h}_{1}\right| \\
\left(\mathrm{kJ} / \mathrm{kg}_{\mathrm{a}}\right)\end{array}$ & $\begin{array}{c}\left|\mathrm{x}_{2}-\mathrm{x}_{1}\right| \\
\left(\mathrm{kg} / \mathrm{kg}_{\mathrm{a}}\right)\end{array}$ & $\begin{array}{c}\mathrm{D}_{\text {air }} \\
(\mathrm{kg} / \mathrm{h})\end{array}$ & $\begin{array}{c}\mathrm{D}_{\text {eau }} \\
(\mathrm{kg} / \mathrm{h})\end{array}$ \\
\hline 1.39 & 0.111 & 0.155 & 56.5 & 0.0085 & 9.6 & 0.08 \\
\hline
\end{tabular}


profitable to use renewable energy (photovoltaic energy) as a source of energy.

\section{Conclusion}

The water-producing refrigeration plant is intended to produce water when the localities to be supplied are inaccessible. Especially as global warming becomes perceptible leading to a lack of water that is accentuated in desert areas, the refrigeration plant with water production can be a hope among the possible solutions to consider for the resolution of this question. The advantage of this solution is that it is inspired by the real and overt phenomena of nature. It is therefore ecologically respective of the preservation of the environment, it merely interprets the principles and laws of the air thermodynamics. However, precautions on the quality of the water must be taken especially with regard to the organ-logical, psycho-chemical parameters; even if the simple filtering of the water makes it possible to limit the microbiological actions. Finally, with the development of renewable energies, we must expect an improvement in its performance and performance.

\section{Acknowledgements}

We would like to thank Professor Nzikou Maturin of the National Polytechnic Graduate School of the University Marien Ngouabi for the assistance he has given us in carrying out this research.

\section{Conflicts of Interest}

The authors declare no conflicts of interest regarding the publication of this paper.

\section{References}

[1] Forum Mondial de L'eau (2018) 18-31 Mars. BRASILIA.

[2] Robert, K. (1998) Les eaux du ciel. Edition Hachette, Paris.

[3] Labouz, L. (2013) Physique de l'atmosphère. Thèse de doctorat de doctorat, Université Blaise Pascal, Aubière France.

[4] Porcher, G. (1987) Cours de Climatisation. Chaud-Froid-Plomberie. Les éditions Parisiennes, France.

[5] Recknagel/Spenger/Honman (1986) Manuel de Génie Climatique. PYC Edition.

[6] Jacquard, P. and Sandre, S. (2004) Pratique du Froid. PYC Edition, Paris.

[7] Perrot, O. (2011) Cours de Machines frigorifiques. Département de Génie Thermique et énergie, I.U.T. de Saint-Omer Dunkerque, France.

[8] Pierre Rapin, J. and Jacquard, P. (1996) Installations Frigorifiques. PYC Edition, Paris.

[9] RIGOT, G. (1991) Transmission et Echangeur de chaleur. Les Editions Parisiennes, France.

[10] MIKASSER, S. (2004) Transfert de masse et chaleur dans les condenseurs. Thèse de doctorat, INSA Lyon, France.

[11] Issoufou Ouedraogo Thèse de Doctorat (2017) Mapping Groundwater Vulnerability 
at the Pan-African Scale. Faculté de Bioingéneuis, Université catholique de Louvain, Belgique.

[12] $20^{\text {ème }}$ Congrès de l'AAE (2019) AFWA Magazine N 125 Aout 2019.

[13] Abdoulaye, F., Alioune, K. and Amadou, L.N. (2017) Influence of Climate Manifestation on Seasonal Rainfall Patterns in Senegal. Journal of Water Sciences.

[14] Yayé MOUSSA Thèse de Doctorat (2018) Précarité hydrique et développement local dans la commune urbaine de Tela au Niger. Université de Toulouse 2, France.

[15] Ouhamdouch, S., Bahir, M. and Carreira, P.M. (2018) Impact du changement climatique sur la ressource en eau en milieu semi-aride. Revue des Sciences de P eau, 31, 13-27. https://doi.org/10.7202/1047050ar

[16] Clément FRENOUX Thèse de Doctorat (2016) Déterminant et performances de services d'approvisionnement en eau dans les villes en développement. Université de Toulouse 1 Capitol, France.

\section{Nomenclature}

$\mathrm{h}_{1} \quad$ Enthalpy of air at state $1\left(\mathrm{~kJ} / \mathrm{kg}_{\mathrm{a}}\right)$

$\mathrm{h}_{2} \quad$ Enthalpy of air at state $2\left(\mathrm{~kJ} / \mathrm{kg}_{\mathrm{a}}\right)$

$\mathrm{x}_{1} \quad$ Absolute humidity of the air at state $1\left(\mathrm{~kg} / \mathrm{kg}_{\mathrm{a}}\right)$

$\mathrm{x}_{2} \quad$ absolute humidity of the air at state $2\left(\mathrm{~kg} / \mathrm{kg}_{\mathrm{a}}\right)$

Qo Cooling capacity $(\mathrm{kW})$

$D_{\text {Water }} \quad$ Water flow $(\mathrm{kg} / \mathrm{h})$

$\mathrm{D}_{\text {air }} \quad$ Air flow $(\mathrm{kg} / \mathrm{s})$

P Compressor power $(\mathrm{kW})$

C.O.P. Performance coefficient

$\varphi \quad$ Relative humidity (\%)

$\Theta \quad$ Temperature $\left({ }^{\circ} \mathrm{C}\right)$

$\Theta_{\mathrm{R}} \quad$ dew temperature $\left({ }^{\circ} \mathrm{C}\right)$

$\mathrm{S} \quad$ Surface $\left(\mathrm{m}^{2}\right)$

$\mathrm{K} \quad$ Heat exchange coefficient $\left(\mathrm{kJ} / \mathrm{C}^{\circ} \mathrm{m}^{2}\right)$ 